\title{
The auditor's liability for audited financial statements
}

\author{
Steven R Firer* \\ B. Comm, B. Compt Hons, MBA, LLM, DBA, CA (SA) \\ Corporate law and financial reporting specialist with Nexia $S A B T$
}

\begin{abstract}
SUMMARY
Two Supreme Court of Appeal judicial decisions have changed the manner in which courts will have to view an auditor's liability to third parties. The first decision was written by Brand JA in Cape Empowerment Trust Limited $v$ Fisher Hoffman Sithole, where he held that a misstatement in the auditor's report by the auditor was grossly negligent but not wrongful. The auditor was afforded immunity from liability for a negligent misrepresentation which consisted of a misstatement in the audit report which rendered the audit report "unusable" thereby defeating the purpose for the auditor's existence. This paper demonstrates that it is clearly wrongful for an auditor to make negligent misstatements in his or her audit report, however it is reasonably possible that the test for legal causation may render the auditor immune from liability. The second decision was written by Navsa JA in Axiam Holdings Ltd $v$ Deloitte \& Touche where he held that an auditor may have a duty to warn a third party about the incorrectness of an audit report even if the auditor is unaware of its incorrectness, and ignorant to whom the warning must be made, if the third party can show that the auditor ought reasonably to have known of the incorrectness. This paper demonstrates that while an auditor has a duty to speak, such a duty cannot exist without a third party to speak to.
\end{abstract}

\section{Introduction}

Two Supreme Court of Appeal (SCA) judicial decisions have "set the cat among the pigeons" when they have regard to the delictual liability of the registered auditor (auditor) ${ }^{1}$ to third parties $^{2}$ in South Africa. The first decision was written by Brand JA in Cape Empowerment Trust Limited $v$ Fisher Hoffman Sithole, ${ }^{3}$ where he held that a misstatement in the auditor's report by the auditor was grossly negligent but not wrongful.

* This paper is dedicated to those foremost authors in the field of delict you know who you are. A gigantic thank you must go to Professor Jooste of the University of Cape Town who wrote the first paper regarding the "silence of the auditors". As usual nothing in the law of delict can be written without reference to words of Professor Johan Neethling, South African law is deeply indebted to you.

1 As defined in s 1 of the Auditing Profession Act 26 of 2005.

2 S 1 of the Auditing Profession Act defines a "client" as: the person for whom a registered auditor is performing or has performed an audit and a "third party" as any person other than a client.

3 Cape Empowerment Trust Limited $v$ Fisher Hoffman Sithole 20135 SA 183 (SCA) Maya, Cachalia, Shongwe JJA and Swain AJA concurring. 
The contentious issue in this court case was that the auditor was afforded immunity from liability for a negligent misrepresentation which consisted of a misstatement in the audit report which rendered the audit report "unusable". This paper demonstrates that it is clearly wrongful for an auditor to make negligent misstatements in his or her audit report, however it is reasonably possible that the test for legal causation may render the auditor immune from liability.

The second decision was written by Navsa JA in Axiam Holdings Ltd $v$ Deloitte \& Touche ${ }^{4}$ where he held that an auditor may have a duty to warn a third party about the incorrectness of an audit report even if the auditor is unaware of its incorrectness, and ignorant to whom the warning must be made, if the third party can show that the auditor ought reasonably to have known of the incorrectness. This decision raises the unsettling issue of a representation by "silence", which could extend an auditor's liability to a third party beyond what may be the generally perceived boundaries. ${ }^{5}$ This paper demonstrates that while an auditor has a duty to speak, such a duty cannot exist without a third party to speak to.

These two court cases have the ability to change the basis upon which the delictual liability of the auditor is determined. For many years the present writer and others have adamantly believed that a negligent auditor is a wrongful auditor. These two court cases change this perception dramatically.

\section{The legal framework}

The delictual liability of auditors to third parties has been regulated since $1951^{6}$ by legislation, which differs from the common law position. ${ }^{7}$ This is reflected particularly in the prescripts of section 46(3) of the Auditing Profession Act 26 of $2005 .^{8}$ Section 46(3) of the Auditing Profession Act creates two significantly different requirements. First, section 46(3)(a) of the Auditing Profession Act "limits" 9 the auditors liability to third parties who can prove: the auditor was negligent in expressing the opinion, or making his or her report or statement; the third party relied upon the opinion, report or statement; suffered loss as a result of the reliance; that the auditor knew or reasonably could have been expected to know at the time the negligence occurred that the third party would rely on the opinion, report or statement. Second, section 46(3)(b) of the Auditing Profession Act provides that if after the audit opinion was given, the registered auditor represented to a third party that it was correct, while

4 Axiam Holdings Ltd $v$ Deloitte \& Touche 20061 SA 237 (SCA) Howie P and Jafta J concurring.

5 Jooste R "The Spectre of Indeterminate Liability Raises its Head" (2006) SALJ 563.

$6 \quad$ Public Accountants' and Auditors' Act 51 of 1951.

$7 \quad$ Neethling Potgieter Visser Law of Delict (2015) 321.

8 Neethling 305.

9 S 46 of the Auditing Profession Act falls under the heading "Limitation of liability". 
at the same time he or she knew or could reasonably have been expected to know that the third party would rely on the opinion, he or she will be liable if the third party suffers loss as a result of the reliance on the negligently given opinion. In other words, the representation to the third party that the report was correct, and the presence of knowledge, real or constructive existed, on the part of the auditor that the third party would rely on the report. ${ }^{10}$

Both section 46(3)(a) and (b) of the Auditing Profession Act provide oversight of the auditor's negligence. It is self-evident that these two provisions cannot cover the same principles. Section 46(3)(a) of the Auditing Profession Act covers the auditor's negligence prior to or at the date the audit report is signed.

Auditors who are unaware of their negligence do not have a legal duty to speak under section 46(3)(a) of the Auditing Profession Act. This provision places the onus on the third party to prove that the auditor was negligent. The wording of this provision makes it clear that section 46(3)(a) of the Auditing Profession Act deals with the auditor's negligence at the time when the negligence occurred, which is either at the date of signing the auditor's report or prior:

"[K]new, or could in the particular circumstances reasonably have been expected to know, at the time when the negligence occurred ... that the opinion, report or statement would be used by a client to induce the third party."

Under this provision Axiam simply had to prove that Deloitte \& Touche were negligent which the judge agreed that they were. There is no obligation for an auditor to express any reservation regarding the audit report as with hindsight they have been judged as negligent. The negligence of Deloitte \& Touche under section 46(3)(a) of the Auditing Profession Act has regard to where the auditors appeared to have foreseen the reasonable possibility of their conduct injuring Axiam. It is self-evident that Deloitte \& Touche did not take reasonable steps to guard against such an injury.

Section 46(3)(b) of the Auditing Profession Act deals with a completely different scenario. This provision deals with the auditor's negligence post signing of the audit report. It is clear that such a provision cannot apply to Axiam. In signing the audit report the auditor makes a representation that his or her opinion is correct at that date and this includes third parties such as Axiam. Section 46(3)(b) of the Auditing Profession Act can only mean that the auditor has made a representation to a third party not foreseeable at the date of signing the audit report. It must be noted that auditors are not liable to any unforeseeable third party.

This has the impact that under section 46(3)(b) of the Auditing Profession Act the auditor must have made a representation directly to a third party who was unforeseeable at the date of signing the audit report

10 Neethling 322 
and must have made contact directly to a third party: "[The auditor] represented, at any time after the opinion was expressed or the report or statement was made, to the third party." In other words while an auditor has a duty to speak under section 46(3)(b) of the Auditing Profession Act, such a duty cannot exist without a third party to speak to.

The typical situation as envisaged by section 46(3)(b) of the Auditing Profession Act is one where a banker calls the auditor to discuss the information on the AFS after signing the audit report and the auditor engages in a discussion with the banker about accounts receivable, inventory, or fixed asset values on the AFS. The auditor readily responds to the enquiries, not once suggesting to the banker that the AFS were misleading. The auditor by engaging in a discussion with the banker makes a representation contemplated by section 46(3)(b) of the Auditing Profession Act.

\section{Cape Empowerment Trust Limited v Fisher Hoffman Sithole ${ }^{11}$}

This matter arose in the Cape High Court a result of a written sale of business agreement concluded between Cape Empowerment Trust Limited (CET) and another listed company, Paradigm Interactive Media Ltd (Paradigm), for the purchase of a business from a subsidiary of Paradigm (Intella). The written sale agreement included a profit warranty by the seller to the purchaser that the profits of the business purchased were not less than R10 million. CET requested that Fisher Hoffman Sithole (FHS) a firm of auditors, verify the correctness of the profit warranty. FHS issued a profit certificate (audit report) that the profits of the business purchased were not less than R10 million. The audit report proved to be misleading as the profits of the business purchased turned out to be significantly less than R10 million.

CET brought a delictual claim against FHS for the recovery of wasted expenditure incurred as a result of having been induced to enter into a detrimental business contract based on the negligent misstatement in the profit certificate by one of the partners of FHS. The SCA held, unanimously that FHS could not be held liable for a negligent misstatement which caused the CET to enter into a written sale of business agreement for the purchase, in the amount of R137 million, of an unprofitable business from a third party.

The SCA held that wrongfulness had not been established. The SCA held, that it would be unreasonable to impose liability on FHS for a loss to which CET had exposed itself, and hence rendered itself vulnerable, by entangling itself in an agreement so complicated that it would not be able to rely on the contractual remedies available to it.

11 Cape Empowerment Trust Limited v Fisher Hoffman Sithole 20135 SA 183 (SCA). 


\section{Axiam Holdings Ltd v Deloitte \& Touche ${ }^{12}$}

It was alleged by Axiam Holdings Ltd (Axiam) that the Business Bank's (TBB) AFS misrepresented its net worth - reflecting a profit before tax of R29 266176 whereas, in fact, it had suffered a loss of R77 899 201. The third party from whom Axiam obtained title to sue, in subsequently purchasing the TBB, relied on an audit report by Deloitte $\&$ Touche, a firm of auditors, in terms of which it opined that the AFS fairly presented the TBB's financial position. It was Axiam's case that Deloitte \& Touche knew or ought to have known that reliance was to be placed on the audit report and that in the circumstances had a duty to warn the third party about the inaccuracies in the AFS.

Deloitte \& Touche excepted to Axiam's particulars of claim on the basis that, on the facts presented, it did not owe the purchaser a legal duty to inform it of the errors in the AFS of the TBB and that the failure to warn the purchaser was insufficient in law to constitute a representation in terms of section 20(9)(b)(ii) of the Public Accountants' and Auditors' Act 80 of 1991, which became "word for word" section 46(3)(b) of the Auditing Profession Act.

\section{The cause of action}

The legal matrix in which the plaintiff third party's claim in both these court cases were placed and judged, was that of "negligent misrepresentation" which causes pure economic loss, as opposed to physical injury to person or property, and not made in a contractual context. Such a claim is recognised in South African law as one of the instances of the application of the extended actio legis Aquiliae. This was established by the Appeal Court in Administrateur, Natal $v$ Trust Bank van Afrika Bpk. ${ }^{13}$

This action has since been affirmed in Siman and Co (Pty) Ltd $v$ Barclays National Bank Ltd: ${ }^{14}$ Lillicrap. Wassenaar and Partners $v$ Pilkington Brothers (SA) (Pty) Ltd; ${ }^{15}$ Bayer South Africa (Pty) Ltd v Frost; ${ }^{16}$ Mukheiber $v$ Raath: ${ }^{17}$ Fourway Haulage SA (Pty) Ltd $v$ SA National Roads Agency Ltd: ${ }^{18}$ and Delphisure Group Insurance Brokers Cape (Pty) Ltd $v$ Dippenaar; ${ }^{19}$ Reflecting the general principles and requirements of Aquilian liability in South African law, the action is available to a plaintiff who can establish:

12 Axiam Holdings Ltd $v$ Deloitte \& Touche 20061 SA 237 (SCA).

13 Administrateur, Natal v Trust Bank van Afrika Bpk 1979 (3) SA 824 (A).

14 Siman and Co (Pty) Ltd $v$ Barclays National Bank Ltd 19842 SA 888 (A).

15 Lillicrap, Wassenaar and Partners $v$ Pilkington Brothers (SA) (Pty) Ltd 19851 SA 475 (A).

16 Bayer South Africa (Pty) Ltd v Frost 19914 SA 559 (AD).

17 Mukheiber $v$ Raath 19993 SA 490 (A).

18 Fourway Haulage SA (Pty) Ltd v SA National Roads Agency Ltd 20092 SA 150 (SCA).

19 Delphisure Group Insurance Brokers Cape (Pty) Ltd v Dippenaar 20105 SA 499 (SCA). 
that in making the misstatement the auditor concerned acted wrongfully; the auditor acted negligently; that the plaintiff third party suffered loss; that the said damage was caused by the misstatement; and that the damages claimed represent proper compensation for such loss. ${ }^{20}$

In all the cases cited above the SCA cautioned against the danger of limitless liability produced by the application of the extended Aquilian action. According to Corbett CJ in Bayer South Africa (Pty) Ltd v Frost: ${ }^{21}$

"[T]he duty of the Court (a) to decide whether on the particular facts of the case there rested on the defendant a legal duty not to make a misstatement to the plaintiff (or, to put it the other way, whether the making of the statement was in breach of this duty and, therefore, unlawful) and whether the defendant in the light of all the circumstances exercised reasonable care to ascertain the correctness of his statement; and (b) to give proper attention to the nature of the misstatement and the interpretation thereof, and to the question of causation."

Olivier JA explained in Mukheiber $v$ Raath ${ }^{22}$ that:

"The danger of limitless liability in particular as far as negligent misrepresentation as a cause of action is concerned can be averted if careful consideration is given to the dictates of public policy, keeping in mind that public policy can easily become an unruly horse." 23

\section{The representations}

In Axiam Holdings Ltd $v$ Deloitte \& Touche, ${ }^{24}$ Deloitte \& Touche conducted an audit and on 1 July 1999 issued an auditor's report that included the following representations:

"In our opinion, these annual financial statements fairly present, in all material respects, the financial position of the company at 31 March 1999 and the results of its operations and cash flow for the period then ended in accordance with generally accepted accounting practice and in the manner required by the Companies Act."

In Cape Empowerment Trust Limited $v$ Fisher Hoffman Sithole, ${ }^{25}$ the profit certificate contained the following representation: "I am satisfied that the after tax profit of Intella group for the period 1 March 1999 to 30 June 1999 amounted to in excess of R10 million."

20 Bayer South Africa (Pty) Ltd $v$ Frost supra 568 B - D for a statement of these requirements.

21 Bayer South Africa (Pty) Ltd $v$ Frost supra 568 D.

22 Mukheiber v Raath supra.

23 Mukheiber $v$ Raath supra para 7.

24 Axiam Holdings Ltd $v$ Deloitte \& Touche supra para 3.

25 Cape Empowerment Trust Limited v Fisher Hoffman Sithole supra para 8. 


\section{Falsity of the representation}

In Axiam Holdings Ltd $v$ Deloitte \& Touche ${ }^{26}$ the representations made by Deloitte \& Touche were incorrect. The 1999 AFS failed to present fairly financial "health" of Axiam. Deloitte $\&$ Touche failed to discover: a bad debt valued at R29 million which was accounted for incorrectly as goodwill; non-existent income in an amount of R10 million; and an irrecoverable debt worth R28 million, which was accounted for incorrectly as a loan to a shareholder. Had the auditor discovered these errors the AFS would have fairly represented TBB's financial "health", or alternatively, the auditor's would have contained a qualified audit opinion.

In Cape Empowerment Trust Limited $v$ Fisher Hoffman Sithole ${ }^{27}$ it was discovered that the profit of Intella group for the period 1 March 1999 to 30 June 1999 did not exceed of R10 million. Had the auditor performed his work sufficiently and appropriately the report would have revealed this deficiency.

\section{Negligence}

In considering the question of negligence, it is necessary to consider the foreseeability of harm.

\section{In Cape Empowerment Trust Limited $v$ Sithole ${ }^{28}$ Binns-Ward AJ explained:}

"Nield [the auditor] must have, or at least should have appreciated that the information was being sought for a serious purpose related to what he knew to be the business of the meeting. Nield should moreover have foreseen that if the warranted profits had not been attained, the implication to the intending purchaser would be that the business had not achieved a significant turnaround in its business fortunes that the warranted profit figure would suggest."

Also relevant to the question of negligence is whether steps could have been taken to guard against the loss. In this context Brand JA stated as follows:

"AMT Technologies, the subsidiary of Intella which rendered the invoice of R10 249800 to Ubunye, raised very serious doubts and pertinent questions about the validity of the claim. Nield proceeded to issue the profit certificate based on this doubtful claim, apparently without any further investigation ... This is why I believe the finding of gross negligence was justified."

26 Axiam Holdings Ltd $v$ Deloitte \& Touche supra para 4.

27 Cape Empowerment Trust Limited $v$ Fisher Hoffman Sithole supra para 9.

28 Cape Empowerment Trust Limited v Fisher Hoffman Sithole 19993 SA 490 (A). 
In Axiam Holdings Ltd $v$ Deloitte \& Touche, ${ }^{29}$ the issue was not whether the misstatements in the audit report were negligent, although that was clearly the case, it was about whether Deloitte \& Touche's failure to warn Axiam as to the errors in the AFS, when it had actual or constructive knowledge that Axiam would rely on the correctness of the audit. This reliance should have been foreseeable prior or at the date of signing the audit report.

In Mccann V Goodall Group Operations (Pty) $L t d,{ }^{30}$ Van Zyl J made some crucial comments as follows:

"[T]he defendant [Mccan], through his experience as a motor-vehicle salesman, must have known that a dealer could be exempted from payment of general sales tax. It was also held that the defendant knew that dealers who sold vehicles to the public had to be registered as such and had to be the holders of a general sales tax certificate. The defendant likewise knew that a seller would be penalised for not collecting the requisite general sales tax from any purchaser other than a registered dealer. In this regard the court was satisfied that the defendant had a legal duty to disclose to the plaintiff that he was not thus registered and had breached such duty by negligently failing to inform the plaintiff accordingly. This would amount to a negligent misrepresentation in the form of a negligent omission to make the said disclosure."

Navsa JA Axiam Holdings Ltd $v$ Deloitte \& Touche ${ }^{31}$ was of the view:

"[A] reasonable person in the defendant's position would ... have known of the defects in the report. On that basis one ... possessed of such knowledge, the reasonable person would not have kept silent but have expressed at least a reservation as to the reliability of the report .... It is clear from the essentials of Axiam's alternative claim that it relies on a negligent misstatement by omission (during the period 1 July 1999 to 22 February 2000) to the effect that Deloitte's prior (negligent) certification was correct. This cannot be faulted either notionally or conceptually."

\section{Wrongfulness}

Wrongfulness - sometimes also referred to as unlawfulness - is one of the elements of delictual liability. ${ }^{32}$ South African law has made wrongfulness a central element of delictual liability. ${ }^{33}$ It is held that this element is important to police the ambit of the law of delict - it would otherwise be too wide if all harm that was brought about negligently was regarded as actionable.

In Trustees for the Time Being of Two Oceans Aquarium Trust $v$ Kantey \& Templer (Pty) Ltd:

29 Axiam Holdings Ltd $v$ Deloitte \& Touche paras 20, 21 and 22.

30 Mccann V Goodall Group Operations (Pty) Ltd 19952 SA 718 (C) 279.

31 Axiam Holdings Ltd $v$ Deloitte \& Touche supra paras 20, 21 and 22.

32 FDJ Brand "Aspects of Wrongfulness: A Series of Lectures" 2014 Stell LR 451 .

33 Brand (2014) Stell LR 451. 
"Negligent conduct giving rise to damages is, however, not actionable per se. It is only actionable if the law recognises it as wrongful ... Where the element of wrongfulness becomes less straightforward is with reference to liability for negligent omissions and for negligently caused pure economic loss." 34

In these instances, it is said, wrongfulness depends on the existence of a legal duty not to act negligently. The imposition of such a legal duty is a matter for judicial determination involving criteria of public or legal policy consistent with constitutional norms. ${ }^{35}$ Whether a particular harm is wrongful or not depends on judicial discretion. ${ }^{36}$ It is said that the criterion for the determination of wrongfulness is a general criterion of reasonableness, whether it would be reasonable to impose a legal duty on the defendant ${ }^{37}$

Where that terminology is employed, however, it is to be borne in mind that what is meant by reasonableness in the context of wrongfulness is something different from the reasonableness of the conduct itself which is an element of negligence. ${ }^{38}$ It concerns the reasonableness of imposing liability on the defendant. 39

\section{Brand JA explains in Trustees for the Time Being of Two Oceans Aquarium Trust $v$ Kantey \& Templer (Pty) Ltd: 40}

"When we say that a particular omission or conduct causing pure economic loss is 'wrongful' we mean that public or legal policy considerations require that such conduct, if negligent, is actionable; that legal liability for the resulting damages should follow. Conversely, when we say that negligent conduct causing pure economic loss or consisting of an omission is not wrongful, we intend to convey that public or legal policy considerations determine that there should be no liability; that the potential defendant should not be subjected to a claim for damages, his or her negligence notwithstanding. In such event, the question of fault does not even arise. The defendant enjoys immunity against liability for such conduct, whether negligent or not. Perhaps it would have been better in the context of wrongfulness to have referred to a 'legal duty not to be negligent', thereby clarifying that the question being asked is whether in the particular circumstances negligent conduct is actionable, instead of just to a 'legal duty',"

34 Trustees for the Time Being of Two Oceans Aquarium Trust $v$ Kantey \& Templer (Pty) Ltd 20071 SA 240 (SCA) para 10; Minister of Safety and Security $v$ Van Duivenboden 20026 SA 431 (SCA) para 12; Gouda Boerdery BK $v$ Transnet 20055 SA 490 (SCA) para 12.

35 Administrator, Natal $v$ Trust Bank van Afrika Bpk supra 833A; Minister of Safety and Security $v$ Van Duivenboden 20026 SA 431 (SCA) para 22; Gouda Boerdery BK $v$ Transnet supra para 12.

36 Brand (2014) Stell LR 462.

37 Government of the Republic of South Africa $v$ Basdeo and another 19961 SA 355 (A) 367E-G; Gouda Boerdery BK v Transnet supra para 12.

38 Trustees for the Time Being of Two Oceans Aquarium Trust $v$ Kantey \& Templer (Pty) Ltd supra para 12.

39 Anton Fagan "Rethinking wrongfulness in the law of delict" 2005 SALJ 109.

40 Trustees for the Time Being of Two Oceans Aquarium Trust $v$ Kantey \& Templer (Pty) Ltd supra. 
The question arises for any jurist, legal scholar or a university student is how would a court in South Africa determine wrongfulness? Paizes describes wrongfulness as "confusing, unclear, contradictory and vague". 41

Leach JA in Delphisure Group Insurance Brokers Cape (Pty) Ltd $v$ Dippenaar, ${ }^{42}$ considered the following relevant policy factors assembled from previous court decisions:

"[1] Whether the plaintiff was vulnerable to the risk (which would favour a finding of liability) or could have avoided it by contractual means such as a disclaimer (which would operate against liability); [2] Whether the extension of liability would impose an unwarranted burden on a defendant or, conversely, whether it would not unreasonably interfere with the defendant's commercial activities as the defendant was already under a duty to take reasonable care in respect of third parties; [3] The nature of the relationship between the parties, contractual or otherwise; [4] Whether the relationship between the parties was one of 'proximity' or closeness; [5] Whether the statement was made in the course of a business context or in providing a professional service; [6] The professional standing of the maker of the statement; [7] The extent to which the plaintiff was dependent upon the defendant for information and advice; [8] The reasonableness of the plaintiff relying on the accuracy of the statement."

Consideration number one known as "vulnerability to risk" has gained substantial importance as regards determining wrongfulness. In fact in Cape Empowerment Trust Limited $v$ Fisher Hoffman Sithole ${ }^{43}$ despite the other seven considerations listed above, "vulnerability to risk" became the only factor in providing the auditor FHS immunity from liability. It is inconceivable that the SCA failed to consider the applicability of section 46(3)(a) of the Auditing Profession Act.

The impact of such a provision is that the auditor will incur liability, subject to the determination of wrongfulness, if the third party can prove the auditor was negligent in the performance of his or her duties. The finding of gross negligence by the court aquo and the SCA indicates to any right minded person that the auditor incurs liability to a third party subject to the assessment of wrongfulness.

It is important to stress that the public and legal policy regarding the auditor's liability to third parties has as its essence the courts acceptance that a third party has suffered loss as a result of the negligence of the auditor. What the SCA failed to recognise is that a negligent auditor is an anathema to society and it is inconceivable that an auditor who is negligent in the role that society has mandated for them is not wrongful. If Brand JA and Maya, Cachalia, Shongwe JJA and Swain AJA had considered the other seven policy factors as set out in Delphisure Group

41 Andrew Paizes "Making Sense of Wrongfulness" 2008 SALJ 371.

42 Delphisure Group Insurance Brokers Cape (Pty) Ltd v Dippenaar supra 508509.

43 Cape Empowerment Trust Limited $v$ Fisher Hoffman Sithole supra para 9. 
Insurance Brokers Cape (Pty) Ltd $v$ Dippenaar ${ }^{44}$ it is highly probable that the auditor would have incurred compensatory liability to the third party. However, based on Brand JA's views regarding the different roles in delictual liability of negligence and wrongfulness, that by according weight to negligence in imposing liability on the auditor, it tantamounted to confusing wrongfulness and negligence. It is wrongful for an auditor to negligently render a set of AFS "unsuitable" for use, and no it is not confusing wrongful with negligence. It is the act of rendering the AFS "unsuitable" that is embodied in the wrongfulness element of delict. The SCA had "judicial myopia" 45 when it came to the language as contained in section 46(3)(a) of the Auditing Profession Act and the role played by the auditor in society.

In applying the "vulnerability to risk" Brand JA explained:

"[V]ulnerability to risk signifies that the plaintiff could not reasonably have avoided the risk of harm by other means ... What is now well established in our law is that a finding of non-vulnerability on the part of the plaintiff is an important indicator against the imposition of delictual liability on the defendant."

What Brand JA was implying in his judgment was that the CET could reasonably have avoided the harm by other means and therefore simply based on this consideration the auditor was afforded immunity from liability. There are a number of crucial reasons why such a conclusion is not above any criticism. Neethling and Potgieter are of the view: "[I]t appears that perhaps too much emphasis was placed on "vulnerability to risk" as a factor determining wrongfulness." 46

Audits serve a vital economic purpose and play an important role in serving the public interest to strengthen accountability and reinforce trust and confidence in financial reporting. The users of financial information need not just information, but accurate, reliable as well as quality information, thus they depend on auditors to serve as objective intermediaries who will lend credibility to the financial information.

The question is how does the auditor fulfil such a mandate? It is through the medium of the audit report through which the auditor communicates with shareholders, creditors, employees and with the public at large. The only observable outcome of the audit process is the issued audit report. The auditor's "error" permitted a person to suffer loss which is a right protected in the South African Constitution (not to be arbitrarily deprived of property) and by affording immunity to the auditor for a negligent misrepresentation in its only available means of communicating with society renders the financial information which

44 Delphisure Group Insurance Brokers Cape (Pty) Ltd v Dippenaar supra 508509.

45 A phrase created by the author.

46 Neethling \& Potgieter "Vulnerability to Risk as a Factor Determining Delictual Liability for Pure Economic Loss” (2015) THRHR 638. 
must be protected, not fit for purpose and thereby defeats the purpose for the auditor's existence.

Centlivres CJ in Herschel $v$ Mrupe ${ }^{47}$ describes the public interest role of those professional persons who offer their services to the public for reward, in which they offer their knowledge and skills in the services of others and that have responsibilities and obligations to those who rely on their work: "Certain functionaries such as sworn appraisers, notaries and the like have had a kind of patent of credibility and efficiency conferred upon them by public authority."

The auditor as one of these persons has a duty to furnish the correct information in his or her official capacity. The reason is that members of the public are invited and entitled to repose confidence and trust in the acts of an auditor in his official capacity. Also there was no question of limitless liability in this case as the claim was by a single identifiable plaintiff for a single loss occurring but once and which was unlikely to bring in its train a multiplicity of actions. ${ }^{48}$ Moreover, the defendant knew that the plaintiff would rely on his profit certificate. ${ }^{49}$

In Holtzhausen $v$ ABSA Bank $L t d^{50}$ the plaintiff undertook to deliver a number of uncut diamonds of which he had been the owner, to a person (A) (whom he had met fortuitously) as agent for an unidentified buyer (B) for an amount of R500 000. The plaintiff furthermore undertook to pay A R20 000 in commission if the contract of sale was concluded. A informed the plaintiff that the purchase price had been paid into the latter's account and supplied three telephone numbers to verify this.

Having established that the money had been paid into his account, and assuming that payment took place by way of a cheque, the plaintiff informed the bank manager $(\mathrm{C})$ of the transaction so that $\mathrm{C}$ could determine whether it was safe to proceed with the transaction and hand over the diamonds. The three telephone numbers were also given to $\mathrm{C}$.

After investigating the matter, $\mathrm{C}$ ensured the plaintiff that the purchase price was safe and that he could proceed with the transaction. C personally authorised the withdrawal of R20 000 in commission to A. Subsequently it transpired that fraud had been committed and that the credit on the plaintiff's account was withdrawn by the bank. The plaintiff claimed damages from the bank.

On appeal the plaintiff based his claim not on breach of a contractual obligation, but rather on delict for pure economic loss; and it was clearly stated that "a right which he had independently of any such contract, was

47 Herschel $v$ Mrupe 19543 SA 464 (A).

48 Fourway Haulage SA (Pty) Ltd v SA National Roads Agency Ltd supra.

49 Delphisure Group Insurance Brokers Cape (Pty) Ltd v Dippenaar supra 508509.

50 Holtzhausen $v$ Absa Bank Ltd 20085 SA 630 (SCA). This narrative has been extracted from: Neethling \& Potgieter “'Vulnerability to Risk” As a Factor Determining Delictual Liability for Pure Economic Loss” (2015) THRHR 641. 
infringed". The plaintiff countered by arguing that $\mathrm{C}$ had not acted wrongfully.

Cloete JA disagreed with the defendant. He explained: ${ }^{51}$

"So far as unlawfulness is concerned, the following findings might be made on the evidence led thus far: That the statement by the bank manager was made in response to a serious request; that the plaintiff approached the bank manager because of his expertise and knowledge of banking matters; and that the plaintiff's purpose in making the enquiry was, to the knowledge of the bank manager, to ascertain whether he could safely proceed with the transaction. It could be inferred that the bank manager realised that the plaintiff would rely on his answer. On the evidence led thus far, it might further be found that there are no considerations of public policy, fairness or equity to deny the plaintiff a claim; that no question of limitless liability could arise; and that an unfair burden would not be placed on the manager or the bank if liability were to be imposed inasmuch as the manager could have refused to act on the plaintiff's request and could have protected himself and the bank against the consequences of any negligence on his part by a disclaimer."

Wrongfulness in Axiam Holdings Ltd $v$ Deloitte \& Touche ${ }^{52}$ had regard to the following:

"Although the application of the criterion of a reasonable person concerns the negligence aspect of liability, from which the legal duty element is quite separate, the provisions of s 20(9)(b)(ii) of the Act provide a clear pointer that a negligent representation falling within its terms is indeed wrongful ... Whether the representation by silence alleged in this case does fall within the section's terms depends on whether there was a duty to speak. In other words the duty relied on for there having been a representation will be the same duty relied on for the allegation of wrongfulness ... As to the existence of that duty, a court apprised of all the factors and circumstances referred to in Minister of Law and Order $v$ Kadir at 318H-I could find, on the framework of the allegations made in the particulars of claim, and on final evaluation, that the defendant's ignorance of its negligent report is no bar to concluding that it bore the alleged duty"

\section{Causation}

As far as factual causation is concerned, the SCA follows the condictio sine qua non - or "but for" - test. ${ }^{53}$ In accordance with this test, as Corbett CJ explained in International Shipping Co (Pty) Ltd $v$ Bentley: ${ }^{54}$ "[O]ne must make a hypothetical enquiry as to what probably would have happened but for the wrongful conduct of the defendant."

51 Holtzhausen $v$ Absa Bank Ltd supra 635.

52 Axiam Holdings Ltd $v$ Deloitte \& Touche supra.

53 Minister of Police $v$ Skosana 1977 1 SA 311 (A) 34 F-35 G.

54 International Shipping Co (Pty) Ltd v Bentley supra 700F-G. 


\section{Brand JA stated in Cape Empowerment Trust Limited $v$ Fisher Hoffman Sithole: ${ }^{55}$}

"In applying this test Binns-Ward AJ held - and I believe rightly so - that had the profit certificate reflected the true financial position of the Intella business, CET's shareholders would not have approved the transaction which would in turn have caused the train of events to come to an abrupt halt."

Once factual causation has been established, however, the question of limiting the defendant's liability for the factual consequences of his or her conduct arises. ${ }^{56}$ The SCA has in this context has always applied the test of so-called "legal causation". 57

\section{Brand JA stated in Cape Empowerment Trust Limited $v$ Fisher Hoffman Sithole: ${ }^{58}$}

"Having said that, it is equally apparent, on the other hand, that wrongfulness and remoteness are not the same in all respects. They involve two different elements of the law of delict, each with its own characteristics and content. Even where negligent conduct resulting from pure economic loss is for reasons of policy found to be wrongful, the loss may therefore, for other reasons of policy, be found to be too remote and therefore not recoverable ... Determination of remoteness also requires application of yardsticks such as foreseeability and direct consequences which do not play a role in establishing wrongfulness."

A defendant should be liable for all the "direct consequences" of his or her negligent conduct. ${ }^{59}$ However a defendant does not act negligently towards a plaintiff unless it is reasonably foreseeable that the particular plaintiff will be injured.

Accordingly, the defendant is not liable to an unforeseeable plaintiff, even though the harm has flowed directly from the defendant's conduct, and despite the fact that it is foreseeable that other persons may have been injured.

Brand JA made some crucial comments in this regard: 60

"With regard to foreseeability CET contended that the wasted expenses for which it claims resulted from the implementation of the business sale agreement and were thus foreseeable by Nield when he made the misstatement on 3 December 1999. As far as the statement goes, it seems to be correct. However, what was not foreseeable by Nield, as I see it, is that CET would not avail itself of the contractual safety nets - a due diligence investigation by its own auditors and the profit warranty - that were

55 Cape Empowerment Trust Limited $v$ Fisher Hoffman Sithole supra para 20.

56 Cape Empowerment Trust Limited $v$ Fisher Hoffman Sithole 1999 supra para 35.

57 International Shipping Co (Pty) Ltd $v$ Bentley supra; Standard Chartered Bank of Canada v Nedperm Bank Ltd 19944 SA 747 (A) 764.

5820135 SA 183 (SCA) para 36.

59 Neethling 205.

60 Cape Empowerment Trust Limited v Fisher Hoffman Sithole supra para 9. 
stipulated in its favour in terms of the business sale agreement. On the contrary, the most likely inference, I think, is that if Nield were to have applied his mind to the potential consequences of a misstatement, he would have thought that even if his statement proved to be untrue, CET would be adequately protected by the safety nets for which it had stipulated. After all, these safety nets were installed to provide precisely for that eventuality."

The "vulnerability to risk" consideration appears to bear a resemblance to the formulation of the test for legal causation, which is concerned with whether it would be reasonable to hold the defendant auditor liable. ${ }^{61}$ The application of the "vulnerability to risk" consideration shifts the blame from the defendant auditor to the plaintiff client who had the ability to extricate itself from the risk that caused it to suffer financial loss and it did not.

If the auditor in Cape Empowerment Trust Limited $v$ Fisher Hoffman Sithole, ${ }^{62}$ should have been immune to liability the reason provided should have been remoteness and definitely not wrongfulness. The fact that CET did not "immediately latch on to the opportunity to extricate itself from the business sale agreement which had lapsed ... that the maze-like structure of agreements in which CET entangled itself did not allow it", together with the unforeseeability of the potential consequences places the loss suffered by CET squarely on the shoulders of CET. This is the "crux" of legal causation. This has nothing to do with wrongfulness, an auditor's negligent conduct of his or her audit and the resultant misstatements are clearly wrongful.

An auditor was appointed as the statutory auditor of the Deals Group of Companies. ${ }^{63} \mathrm{~A}$ third party International Shipping provided various financial facilities to the Deals Group.

The Deals Group was liquidated in 1981. International Shipping claimed damages from the auditors on the basis that the AFS he had audited were materially false and misleading. The SCA held that there was conduct and that the conduct had been both wrongful and negligent. The question that remained was whether the factual causation between the conduct and the harm was sufficiently close for the court to attribute liability to the auditors.

Here the court held that International Shipping had allowed the Deals Group's indebtedness to escalate in an uncontrolled way. In addition, International Shipping had become involved in the Deals Groups administration and had significant insight into the Deals Group's financial affairs. A member of the board of directors had been deceived and that International Shipping must have been aware of the deception, or at least suspected the dishonesty. It was readily apparent that from a policy perspective International Shipping (the third party) despite all the

61 Neethling \& Potgieter "Wrongfulness and Legal Causation as Separate Elements of a Delict: Confusion Reigns” 20144 TSAR 898.

62 Cape Empowerment Trust Limited $v$ Fisher Hoffman Sithole supra para 36.

63 International Shipping Company (Pty) Ltd $v$ Bentley supra. 
"red flags" did not take reasonable care for the protection of its own interests. In other words International Shipping was not vulnerable to risk. They had sufficient insight into the business of the Deals Group to have reduced the risk of financial loss dramatically.

\section{Comments and conclusion}

As regards Cape Empowerment Trust Limited v Fisher Hoffman Sithole, ${ }^{64}$ wrongfulness is established, because public policy requires that auditors be held liable for negligent conduct and thus be incentivised to take adequate care to avoid causing harm to others. ${ }^{65}$ For the community it would inconceivable that an auditor who made such mistakes as for example in Axiam Holdings Ltd $v$ Deloitte \& Touche ${ }^{66}$ would not be held liable. The community expects auditors not to make mistakes that render the AFS "unusable". There is a great public interest in making sure that auditors in assuming the role of the public watchdog succeed in thwarting avoidable harm. ${ }^{67}$ If they are too easily insulated from claims for these harms because of mistakes on their side, they would have little incentive to conduct themselves in a way that avoids causing harm. ${ }^{68}$ Policy objectives, such as the deterrent effect of liability, underpin one of the purposes of imposing delictual liability. ${ }^{69}$ The convictions of the community as to policy and law clearly motivate for liability to be imposed. ${ }^{70}$ The auditor's negligent inaccurate statements are therefore wrongful. A reasonable auditor would have foreseen the possibility that the mistakes would cause harm. When one is tasked with protecting the community by giving credibility to the AFS, it is simply not reasonable to make such blatant errors of judgment without adequately verifying what the correct approach should have been.

In respect of the judicial decision in Axiam Holdings Ltd $v$ Deloitte \& Touche, $^{71}$ the essence of the court's decision can be found in the following words of Navsa JA:

“[A] reasonable person in the defendant's position would... have known of the defects in the report. The reasonable person would not have kept silent but have expressed at least a reservation as to the reliability of the report".

The question arises as to whom should such a reservation be made? This does not appear to be a consideration of the court. Without a "to whom" the reservation should be made the prospect of indeterminate liability

64 Cape Empowerment Trust Limited $v$ Fisher Hoffman Sithole supra para 9.

65 Loureiro and Others $v$ Imvula Quality Protection (Pty) Ltd 20143 SA 394 (CC) para 51.

66 Axiam Holdings Ltd $v$ Deloitte \& Touche supra.

67 Loureiro and Others $v$ Imvula Quality Protection (Pty) Ltd supra para 56.

68 Loureiro and Others $v$ Imvula Quality Protection (Pty) Ltd supra para 56.

69 Loureiro and Others $v$ Imvula Quality Protection (Pty) Ltd supra para 56.

70 Loureiro and Others $v$ Imvula Quality Protection (Pty) Ltd supra para 56.

71 Axiam Holdings Ltd $v$ Deloitte \& Touche supra paras 20, 21 and 22. 
appears on the horizon, something that section 46 of the Auditing Profession Act was specifically designed to eliminate.

Section 46(3)(b) of the Auditing Profession Act is clear in that the representation must "in any way represented ... to the third party". This means that the representation explicitly or implicitly (by silence) must be made directly to a third party. This will eliminate any potential for indeterminate liability as any liability is limited to a specific defendant in very specific circumstances. If the judicial decision in Axiam Holdings Ltd $v$ Deloitte \& Touche $e^{72}$ is permitted to stand then there is no doubt that this extends the boundaries of the auditor's liability to third parties which clearly is not the intention of the legislation.

The case of Dimond Manufacturing Company Limited $v$ Hamilton, ${ }^{73}$ illustrates the law "quod sit lex"74 as intentended by the tenets and prescripts of section 46 of the Auditing Profession Act. In Dimond Manufacturing Company Limited $v$ Hamilton, ${ }^{75}$ the auditor was unaware that the AFS were to be used by a potential possible purchaser of shares in the company. A third party potential purchaser, Mr Horwath met with the auditor Mr Meek. At the meeting Mr Meek handed the AFS over to Mr Horwath in order that Mr Horwath make extracts of the AFS to begin negotiations for the purchase of the shares in the company.

Turner J in Dimond Manufacturing Company Limited $v$ Hamilton ${ }^{76}$ held that at the point where no extracts were made or handed over to $\mathrm{Mr}$ Howarth that he [Turner JA]: "would hold that no representation regarding the balance sheet [AFS] had yet been made by Mr Meek." Turner J held that as soon as the AFS were handed over to Mr Horwath:

"[There was] no doubt that at the interview ... by personally producing the balance sheet to him [Mr. Horwath] and acquiescing in his copying its figures, Mr Meek made an implied representation to Mr Howarth as to the correctness of the balance sheet."

Neethling is supportive of this view when he explains that while section 46(3)(b) of the Auditing Profession Act, appears to be aligned with the common law, however important differences exist. Although a negligent breach of an auditor's duty is in principle wrongful, in the case of section 46(3)(b) of the Auditing Profession Act the wrongfulness must be clear towards an identified third party. ${ }^{77}$

This view was also supported by the judgment of Van Zyl J in Mccann $V$ Goodall Group Operations (Pty) $L t d,{ }^{78}$ where the duty to speak was directed towards an identified third party, a Mr Goodall.

72 Axiam Holdings Ltd $v$ Deloitte \& Touche supra.

73 Dimond Manufacturing Company Limited v Hamilton 1969 NZLR 609.

74 The law as it should be.

75 Dimond Manufacturing Company Limited v Hamilton supra.

76 Dimond Manufacturing Company Limited v Hamilton supra 636.

77 Neethling 321.

78 Mccann V Goodall Group Operations (Pty) Ltd supra 279. 
Thus, some contact must take place between the third party and the auditor after the release of the report, during which a representation is in some manner, either expressly or implicitly, made that the report is correct, or, as stated by Cloete JA in Axiam Holdings Ltd $v$ Deloitte \& Touche $e^{79}$ "the auditor must, subsequent to the audit, take responsibility to the third party for its accuracy".

However, it may be extremely difficult for another court to dispel these concerns without differing from the majority. ${ }^{80}$ It is not a matter of the auditing profession being unhappy, it's a matter of serious concern that the SCA ignored the language contained in section 46(3)(b) of the Auditing Profession Act, by suggesting that the key issue is that auditors have a duty to speak even when there is no one to speak to.

79 Axiam Holdings Ltd $v$ Deloitte \& Touche supra para 32.

80 Jooste (2006) SALJ 567. 